\title{
Public health, a major player in urban active transport policies?
}

Carole Clavier, France Gagnon, Sophie Paquin, Katie Hayes, Blake Poland, Beth Savan and Nina Escoute

\section{(2) OpenEdition}

\section{Journals}

Electronic version

URL: http://journals.openedition.org/rfst/765

DOI: $10.4000 /$ rfst.765

ISSN: 2492-3672

Publisher

Espaces et SOciétés (UMR 6590)

Electronic reference

Carole Clavier, France Gagnon, Sophie Paquin, Katie Hayes, Blake Poland, Beth Savan and Nina Escoute, "Public health, a major player in urban active transport policies?", Revue francophone sur la santé et les territoires [Online], Mobility, Transports and Health, Online since 27 May 2019, connection on 06 April 2021. URL: http://journals.openedition.org/rfst/765 ; DOI: https://doi.org/10.4000/rfst.765

This text was automatically generated on 6 April 2021.

\section{c) (i) (2)}

La Revue francophone sur la santé et les territoires est mise à disposition selon les termes de la Licence Creative Commons Attribution - Pas d'Utilisation Commerciale - Partage dans les Mêmes Conditions 4.0 International. 


\title{
Public health, a major player in urban active transport policies?
}

\author{
Carole Clavier, France Gagnon, Sophie Paquin, Katie Hayes, Blake Poland, \\ Beth Savan and Nina Escoute
}

Urban policies that encourage walking or cycling to work are widely considered as healthy public policies given the benefits of increased physical activity, reduced traffic congestion and reduced air pollution. The difficulty for public health actors is that action to promote walking or cycling is largely outside their reach, for instance : building walking and cycling infrastructure (broader sidewalks, cycling lanes, and so on), improving access to public transit, or changing bylaws on maximum speed limits. These actions fall under the responsibility of transportation and urban planning sectors. In other words, creating healthy public policies requires that public health actors partner with actors from other sectors. In doing so, they are likely to come up against " politics and power games » (de Leeuw, 2017, p. 344). This paper explores what public health actors do to integrate a health perspective into urban policies for active transportation. As policy instruments fall under the responsibility of other sectors, what do they do? Are they limited to advocacy efforts? And how can these policy instruments be implemented when these other sectors are primarily concerned with something other than health? To answer these questions, this paper examines the role of public health actors in the process of leading two major Canadian cities, Montreal and Toronto, to develop active transportation policies (the policy emergence phase) and to implement these policies, including specific initiatives to change the built environment for active transportation (the implementation phase). We observe how public health actors, and in particular the local public health authorities, interact with actors from other sectors concerned with active transportation. We also consider how health knowledge and values are used in the legitimisation of active transportation policies. This focus on interactions and values stems from our use of an advocacy coalition framework (Sabatier \& Weible, 2007). The methods include documentary analysis (official plans and documents related to active transportation) and semistructured interviews (Montreal=20, Toronto $=20$ ) with key actors from the active transportation policy subsystem (in particular: municipal councillors and employees; 
public health actors, especially from local public health agencies; representatives from interest groups involved with active transportation).

There are four main results from this study. Firstly, arguments for active transportation based on health benefits have circulated beyond the community of public health actors. Such arguments are found in the official plans stating the objectives of both cities' active transportation policies; in rationales justifying the specific initiatives under study; and in the discourses of actors from other sectors. Secondly, public health actors spend considerable time and effort in the production and diffusion of knowledge regarding the intersections between transportation, urban planning and health. Based on this knowledge, they also adopt public positions on policy issues regarding active transportation. They are, however, largely absent from the implementation phase of the specific active transportation initiatives under study here (figure 1). Third, public health actors engage with actors from other policy sectors that share their values and vision regarding active transportation policies. This is especially true of their interactions with non-governmental organisations and university researchers. Lastly, it is more difficult for them to establish interactions with actors that do not share their values and visions regarding preferred policies, especially with municipal transportation services.

3 In conclusion, our results suggest that the inclusion of health knowledge and values into official plans that state the objectives of active transportation policies is not sufficient to determine that health has become part of active transportation policies. Constitutional rules that define how responsibilities are shared between sectors, and the definition of a policy sector by a dominant profession and a dominant policy paradigm, limit the extent to which public health actors may shape active transportation policies so that they become healthier urban policies.

Figure 1: New configurations of Saint-Laurent Boulevard towards Bellechasse Street in Montreal and of Roncesvalles Street in Toronto

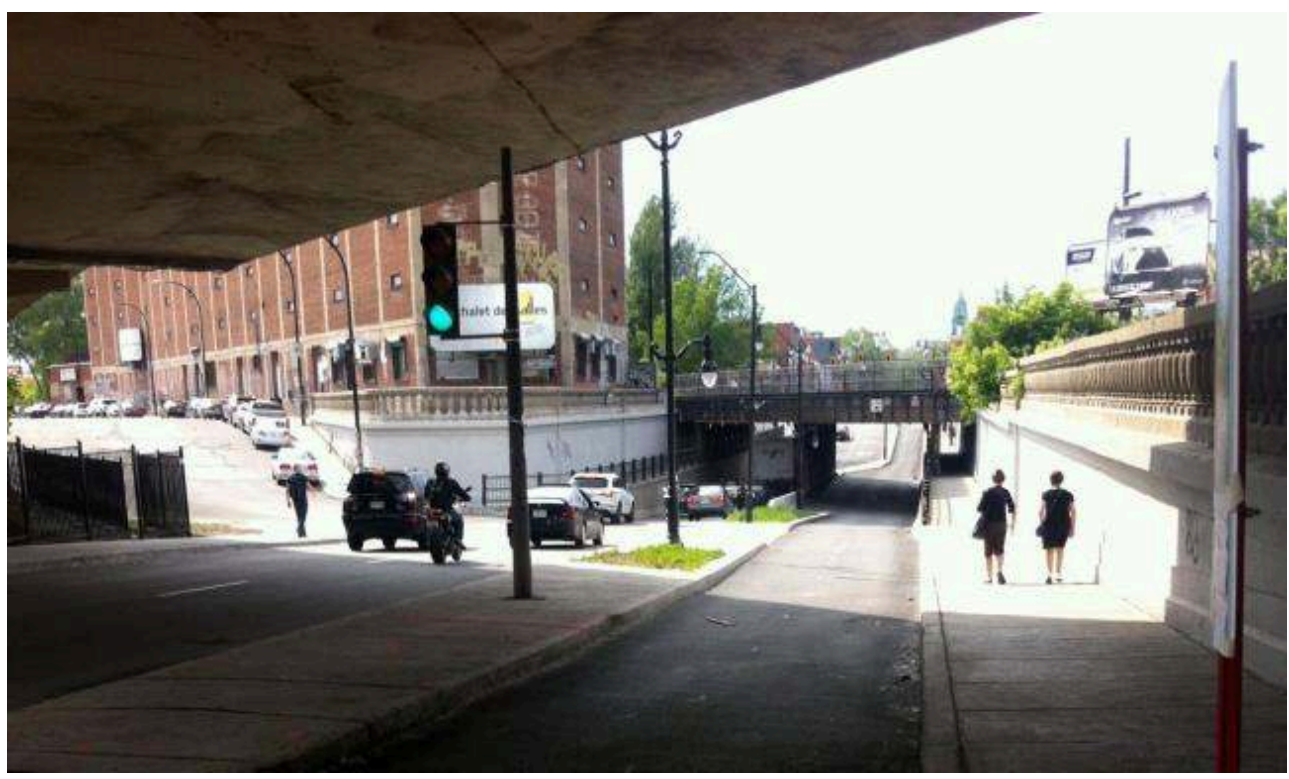

Photo: Nina Escoute, 2015 
New configurations of Saint-Laurent Boulevard towards Bellechasse Street in Montreal and of Roncesvalles Street in Toronto

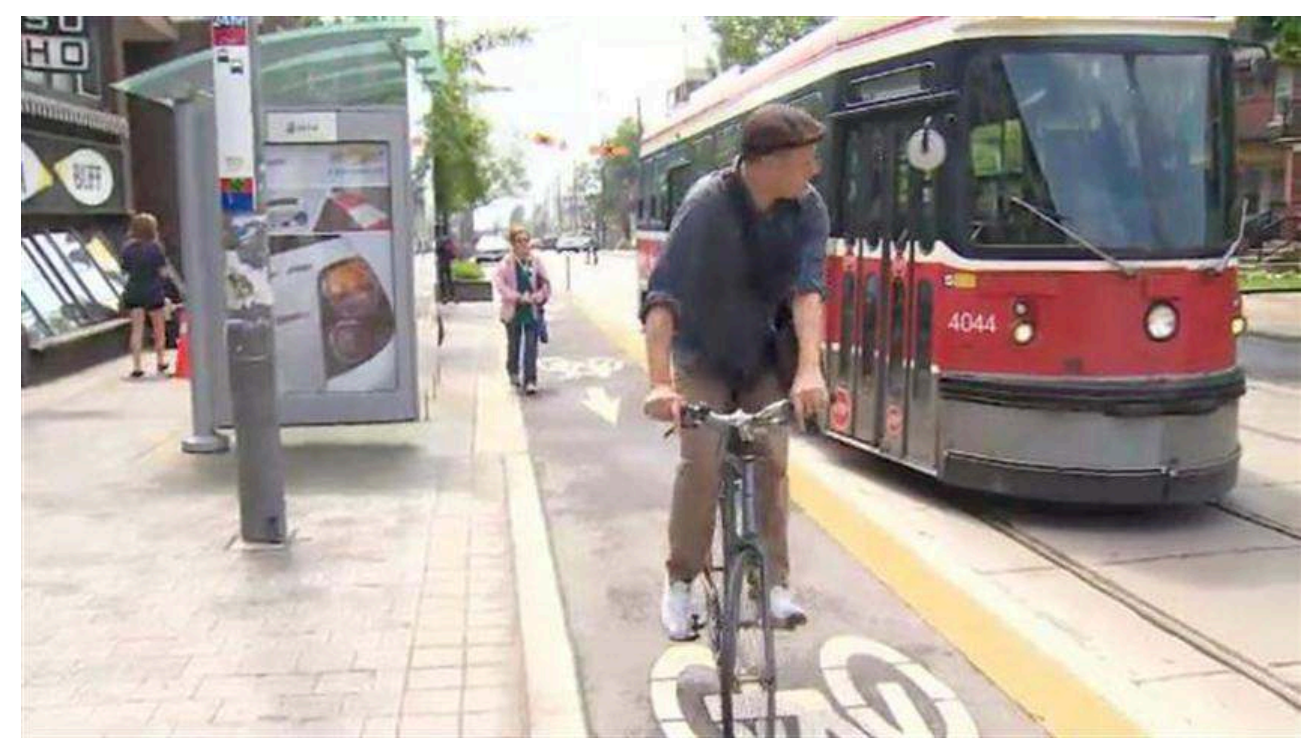

Photo: http://thumbnails.cbc.ca'

\section{BIBLIOGRAPHY}

de Leeuw, E. (2017). Engagement of Sectors Other than Health in Integrated Health Governance, Policy, and Action. Annual Review of Public Health, 38 (1), 329-349. doi:10.1146/annurevpublhealth-031816-044309

Sabatier, P. A., \& Weible, C. M. (2007). The Advocacy Coalition Framework: Innovations and Clarifications. In P. A. Sabatier (Ed.), Theories of the Policy Process. 2nd Edition (pp. 189-220). Boulder, Co: Westview Press.

\section{NOTES}

1. Référence complète : http://thumbnails.cbc.ca/maven_legacy/thumbnails/944/483/ Bikes-Matteis_852x480_2388545144.jpg 
INDEX

Keywords: local policies, transport, public health, urban policies

\section{AUTHORS}

CAROLE CLAVIER

Professeure, Département de science politique, Université du Québec à Montréal

\section{FRANCE GAGNON}

Professeure, École des sciences de l'administration, TÉLUQ

SOPHIE PAQUIN

Professeure, Département d'études urbaines et touristiques, ESG UQAM

KATIE HAYES

Doctorante, Dalla Lana School of Public Health, Université de Toronto

\section{BLAKE POLAND}

Professeur, Dalla Lana School of Public Health, Université de Toronto

BETH SAVAN

Sr. Lecturer (Emeritus), School of the Environment, Université de Toronto

NINA ESCOUTE

Assistante de recherche, Département de science politique, UQAM 